\title{
Book Review: Red Skin, White Masks: Rejecting the Colonial Politics of Recognition
}

\author{
Michelle Lorna Nahanee \\ School of Communication \\ Simon Fraser University
}

Red Skin, White Masks: Rejecting the Colonial Politics of Recognition by Glen Sean Coulthard was launched on Oct. 22nd, 2014 at SFU Woodwards. For more information regarding the book launch and its panel discussion, please visit: http://www.sfu.ca/sfuwoodwards/events/events1/20142015-fall/GlenCoulthardRedSkinWhiteMask.html

Red Skin, White Masks examines anti-colonial efforts of Indigenous resurgence in Canada from 1969 to the present and demonstrates the shift from tradition-based assertions of land and title to negotiated claims for land and recognition. It strips the promise of emancipation from the pursuit of recognition and offers Five Theses on Indigenous Resurgence and Decolonization. READ a book review by Michelle Lorna Nahanee, a member of the Squamish Nation and MA student in Global Communications.

Glen Sean Coulthard's commitment to the demise of capitalism is expressed in his twitter handle @denerevenge/dene communist and in his incisive assertion "for our nations to live, capitalism must die" (p. 174). In Red Skin, White Masks: Rejecting the Colonial Politics of Recognition, Coulthard examines anti-colonial efforts of Indigenous resurgence in Canada from 1969 to the present and demonstrates the shift from tradition-based assertions of land and title to negotiated claims for land and recognition. Coulthard superimposes Karl Marx's "primitive accumulation of capital model" (as cited in p. 152) onto Franz Fanon's conceptions of the effects colonialism to inform his position and produce suggestions for Indigenous nations to move forward. He argues that seeking recognition from the nation-state, such as negotiating for special cultural status and reproducing a colonial binary of dominant/subaltern cultures that supports capitalist accumulation. The book concludes with five theses for the future of Indigenous activism that is an inspiring call to action for First Nations in Canada.

The book is smart but not prescriptive. It provides case studies and detailed analyses from both Indigenous and non-Indigenous scholars that strip the promise of emancipation from the pursuit of recognition to show "how the politics of recognition has come to serve the interests of colonial power" (p. 25). By shifting Indigenous goals from emancipation from the nation-state to recognition $\boldsymbol{b y}$ the nation-state, the power remains with the grantor, of the recognition, in issues ranging from the essentialism of cultural identity (e.g. "who is aboriginal?") to the control and commodification of resources (e.g. "who will benefit?"). By exposing political recognition as a self-perpetuating capitalist concept, which is often presented under the coercive narrative of economic development, Coulthard depicts primitive accumulation as "an ongoing practice of dispossession that never ceases to structure capitalist and colonial social relations in the present" (p. 152). The power of his position is in exposing how dispossession is intrinsically linked to accumulation. His case studies prove how dispossession continues to be negotiated through dominant / subaltern power structures that function contemporarily within Canada as land claims and requests for state-recognition.

Coulthard's First Nations first-person perspective is the unique gift offered by Red Skin, White Masks' examples of First Nations political issues. In his call for a place-based approach to anticolonialism, Coulthard describes his Dene Nation's endeavor to define and pursue selfdetermination. His argument is not only academically insightful but it is uniquely constructed with his application of political theory juxtaposed with the wisdom of his Elders. He applies the model of primitive accumulation to his people's reaction to pipeline development in his Dene territories in

Corresponding Author: Michelle Lorna Nahanee (mnahanee@sfu.ca) 
the 1970s and articulates the resistance efforts that resulted in The Declaration of Dene Nationhood which is a political manifesto demanding the full recognition of the Dene as a self-determining nation (p. 64). The political organization and mobilization that culminated with the Declaration included community meetings with speeches shared by Elders. Coulthard recounts the following profound statement made by Philip Blake, a Dene Elder:

"We have lived with the land, not tried to conquer or control it or rob it of its riches. We have not tried to get more and more riches and power, we have not tried to conquer new frontiers, or out do our parents, or make sure that every year we are richer than the year before. We have been satisfied to see our wealth as ourselves and the land with live with" (p. 63).

Through Blake, an intimate view of Dene epistemology is shared and a deeper level of understanding Indigenous perspectives is gained.

Although The Declaration of Dene Nationhood was passed unanimously at a general assembly on July 19, 1975, it's struggle for "the recognition of the Dene Nation by the governments and peoples of the world" (Dene, 1975) continues. In response to expensive, stalled land claims and other divisive tactics by the Canadian government, Coulthard suggests that First Nations should walk away from the need for recognition and instead operate within Indigenous ways of knowing which he calls "grounded normativity" (p. 13). Reconnecting with land and tradition will build the strength needed to break away from the colonizer/colonized dialectic that continues to erode Indigenous family systems and governance.

A revised Indigenous struggle should be "deeply informed by what the land as a system of reciprocal relations and obligations can teach us about living our lives in relation to one another and the natural world in non-dominating and non-exploitive terms" (p. 13). Clearly inspired by the community voices of the Dene Declaration and pushing back against the pressure of resource development in his territory, he sees the future of his people as more than "rightless proletarians" (p. 13) subsisting on labor jobs in the resource economy and urges Indigenous people to remove the blinders of capitalism to see how the struggle for recognition serves the colonial agenda of dispossession and accumulation.

Another unique strength of Coulthard's book is his inclusion of Indigenous scholars, two of whom he refers to as "theorists of Indigenous resurgence" (p. 154), Taiaiake Alfred and Leanne Betasamosake Simpson. Through Alfred and Simpson, it becomes clear that Fanon's bias for the new over the old, and his call for the colonized to move away from the past, is not applicable to the decolonization of Aboriginal people in Canada. Alfred argues the "renewal of respect for traditional values is the only lasting solution to the political, economic, and social problems that beseech our people" (p. 155) while Sampson suggests "regenerating our political and intellectual traditions" and "articulating and living our legal traditions" (p. 155). It is refreshing to explore perspectives that move beyond typifications of Fanon's internalized colonization. Moving beyond binary constructions of old and new allows us to see traditional cultures as a value to be manifested in contemporary applications - not as inferior systems belonging strictly in the past.

In the conclusion of Red Skin, White Masks: Rejecting the Colonial Politics of Recognition, Coulthard offers Five Theses on Indigenous Resurgence and Decolonization that consolidate and contribute to the debates and conversations within the First Nations movement sparked by Idle No More. The theses are as follows:

1. Promote direct action because these are the only tactics that have been effective.

2. Advocate for the death of capitalism through the construction of Indigenous alternatives.

3. Increase solidarity between urban Aboriginal people and reserve-based First Nations people.

4. Be active against gender inequality for Aboriginal women and see the violence we experience as the responsibility of everyone to fix. 
5. Move beyond nation-state governance so First Nations people discontinue engagement within the self-sustaining settler-colonial patriarchal systems of Canada.

Through his theses, we see that Idle No More is not over because it has the support and, through Coulthard and friends, a working framework for revolution.

But, is it possible to kill capitalism and move out of dominant culture systems without being charged with murder? Have enough First Nations people decolonized their identities to the point where they can say that traditional forms of Indigenous governance are superior to those that constitute Canada? And, can reading a dene communist's manifesto add to the probability of Indigenous resurgence?

Regarding the first two questions, I am unsure but to the question of probability I emphatically answer yes. After reading Red Skin, White Masks, I envision an Indigenous future very different from the view I had prior. The book provides detailed historical analysis paired with well-argued suggestions for Indigenous resurgence as well as 40 pages of references to continue researching the topic. Coulthard's book pushes back against dominant narratives on the "Aboriginal problem" in Canada by uncovering the realities of "the gift" of state recognition as a source of increased legislation and hegemony. And, in the end, in his last sentence, he offers hope for his radical and elegant proposal for the survival of his people, "It is only by privileging and grounding ourselves in these normative life styles and resurgent practices that we have a hope of surviving our strategic engagements with the colonial state with integrity and as Indigenous peoples" (p. 179). In turning away from the struggle for state-recognition, First Nations people can develop systems of self-recognition that will support the growth of their communities in a self-determined, post-colonial context.

\section{References}

Coulthard, G. (2014). Red skin, white masks: Rejecting the colonial politics of recognition. Minneapolis, MN: University of Minnesota Press.

Dene Nation and the Assembly of First Nations North West Territory. (1975, July 19). The Declaration of Dene Nationhood. Retrieved from: www.denenation.com/dene declaration.html 